\title{
LANDSCAPE FACTORS INFLUENCING DIVERSITY OF HABITAT CONDITIONS ACROSS A WATERCOURSE IN THE VICINITY OF TOMASZÓW LUBELSKI CITY IN THE ROZTOCZE REGION (POLAND)
}

Joana SENDER * and Weronika MAŚLANKO *

* University of Life Sciences in Lublin, B. Dobrzańskiego Street 37, Lublin, Poland, 20-262, joanna.sender@up.lublin.pl,weronika.maslanko@up.lublin.pl

DOI: 10.1515/trser-2015-0045

KEYWORDS: river, hydromorphology, River Habitat Survey, RHS, HQA, HMS, purity classes.

\section{ABSTRACT}

The aim of the study was a hydromorphological valorisation of the river valley in the Roztocze region using the British method - River Habitat Survey (RHS). As a result of field research two numerical indicators HMS (Habitat Modification Score) and HQA (Habitat Quality Assessment) were identified and purity water classes were defined. The river did not fulfil the requirements of the Water Framework Directive, because its state was defined as poor and moderate. On the base of physical and chemical parameters, in the majority of water studied the watercourses were classified to the first class of purity. Only in one segment waters were below the first class, or even out of class.

ZUSAMENFFASSUNG: Die Vielfalt von Lebensraumbedingungen in Fließgewässern beeinflussende Landschaftsfaktoren in der Nähe der Stadt Tomaszow Lubelski der Region Roztocze (Polen).

Ziel der Untersuchung war eine hydromophologische Bewertung des Flusstales der Region Roztocze unter Anwendung der britischen Methode zur Habitat Erfassung - River Habitat Survey RHS. Als Ergebnis der Geländeuntersuchungen wurden zwei numerische Indikatoren HMS (Stand der Habitatveränderung HMS) und Habitat Qualitätsbewertung (HQA) identifiziert sowie Wassersauberkeits Klassen definiert. Der Fluss erfüllt nicht die Anforderungen der Wasserrahmenrichtlinie, da sein Zustand als arm und moderat definiert wurde. Anhand von physikalischen und chemischen Parametern wurde das Wasser der untersuchten Fließgewässer mehrheitlich in die erste Sauberkeitsstufe eingegliedert. Lediglich in einem Abschnitt war das Wasser unterhalb der ersten Klasse, oder gar außerhalb jeglicher Klasseneinteilung.

REZUMAT: Factorii de peisaj care influențează diversitatea condițiilor de habitat de-a lungul unui curs de apă (râu) în apropierea orașului Tomaszow Lubelski, în regiunea Roztocze (Poloniei).

Scopul studiului a fost valorificarea hidromorfologică a văii râului din regiunea Roztocze, folosind metoda britanică de evaluare - River Habitat Survey RHS. Ca rezultat al cercetărilor de teren, au fost identificați doi indicatori numerici HMS (Habitat Modification Score/Modificarea Scorului Habitatului) şi HQA (Evaluarea Calității Habitatului), precum și definită o clasă de puritate a apei. Râul nu a îndeplinit cerințele Directivei-Cadru privind apa (Directiva Cadru-Ape), pentru că starea sa a fost definită ca fiind proastă și moderată. Pe baza parametrilor fizico-chimici, în cazul majorităţii apelor cursurilor de apă studiate, acestea au fost clasificate de la prima clasă de puritate. Numai în cazul unui segment de râu apele au fost mai jos de prima clasa de puritate, sau chiar din afara acestei clase. 


\section{INTRODUCTION}

All components of aquatic ecosystems, including river valleys, play important roles (Sender and Maslanko, 2014) in nature. River valleys act as a natural stripes of increased displacement of matter, energy and biological information in the landscape (among others, flow of water and erosion material, the movement the air mass, species migration) (Chmielewski, 2004a; Curtean-Bănăduc et al., 2014). To fulfil functions as ecological corridors, waters should maintain natural or semi-natural character; lead water must not be polluted, should be permeable, and uninterrupted by barrier structures (Chmielewski, 2004b, 2005; Allan et al., 1997). In human history river valleys have always played and still play important functions, including supplying public with water, provision of fish, recreational use, and maintain balance in water management (Byczkowski, 1999; Bajkiewicz-Grabowska and Mikulski, 2007). In past centuries, first civilizations were closely associated with aquatic ecosystems. However, human activities often cause degradation of these sensitive ecosystems. Incorrect management of catchment can cause disturbance or prevent performance of above mentioned functions.

Requirements imposed under the regulations of the Water Framework Directive (Directive 2000/60/EC of 23 October 2000) by the European Union on Member States postulated achieving at least a good ecological status of rivers by 2015. In order to plan river renaturalisation treatments, a unified system of rivers morphological evaluation that allows their comparison on the local or regional level was introduced (Newson et al., 1998; Szoszkiewicz et al., 2009b). Nowadays in Poland the application of a British method called River Habitat Survey (RHS) is increasing (River, 1997, 2003). River Habitat Survey allows the characterisation of rivers and their classification based on hydromorphology. It is a method based on recording elements of the environment (Osowska and Kalisz, 2011).

Protection appears to have had a favourable influence on watercourse function within the respective area. For this reason, studies were undertaken to determine the impact of human activities on the river valley ecosystem. For this reason, studies were undertaken to determine the impact of human activities on the river valley ecosystem. The study area included the Tomaszów watercourse flowing through the city area, as well as the municipality of Tomaszów Lubelski. The studies included: analysis of changes in land use in the catchment area between 1992 and 2012, the basic characteristics of physical and chemical parameters of water, together with an indication of purity class and indication of degradation threats affecting the ecosystem. The ecological status of this watercourse was assessed to determine if it meets the minimal criteria intended by the Water Framework Directive, and to identify areas in need of renaturalisation treatments

\section{MATERIALS AND METHODS}

\section{Study area}

The research area is located in the Roztocze region, in the North-East from the Tomaszów Lubelski city center. The Roztocze is a physico-geographical macroregion situated within Eastern Lesser Poland Upland. It forms a range of gentle hills, stretching over approximately 185 kilometers, from Kraśnik in Poland to Lviv in Ukraine. Hills reach a height of 300-400 meters above sea level, with maximum 150 meters height differences. Hydrographically the region divides the river systems of the Wieprz and the Bug rivers from those of the San and the Dniester rivers (Chmielewski et al., 2014). The research within these studies focussed on the Tomaszów watercourse with its catchment (Fig. 1). The total length of this watercourse is $2,128 \mathrm{~m}$, while the study area, coinciding with the catchment area encompassed 190,034 ha. 
In the vicinity of the study area there are different forms of environment protection. The oldest reserve was established in 1962 called "Piekiełko" near Tomaszów Lubelski, this was followed by the creation of Krasnobród Landscape Park in 1988, and the "Zarośle" reserve in 1998. Most recently the four areas of Natura 2000 network were formed (Fig. 2).

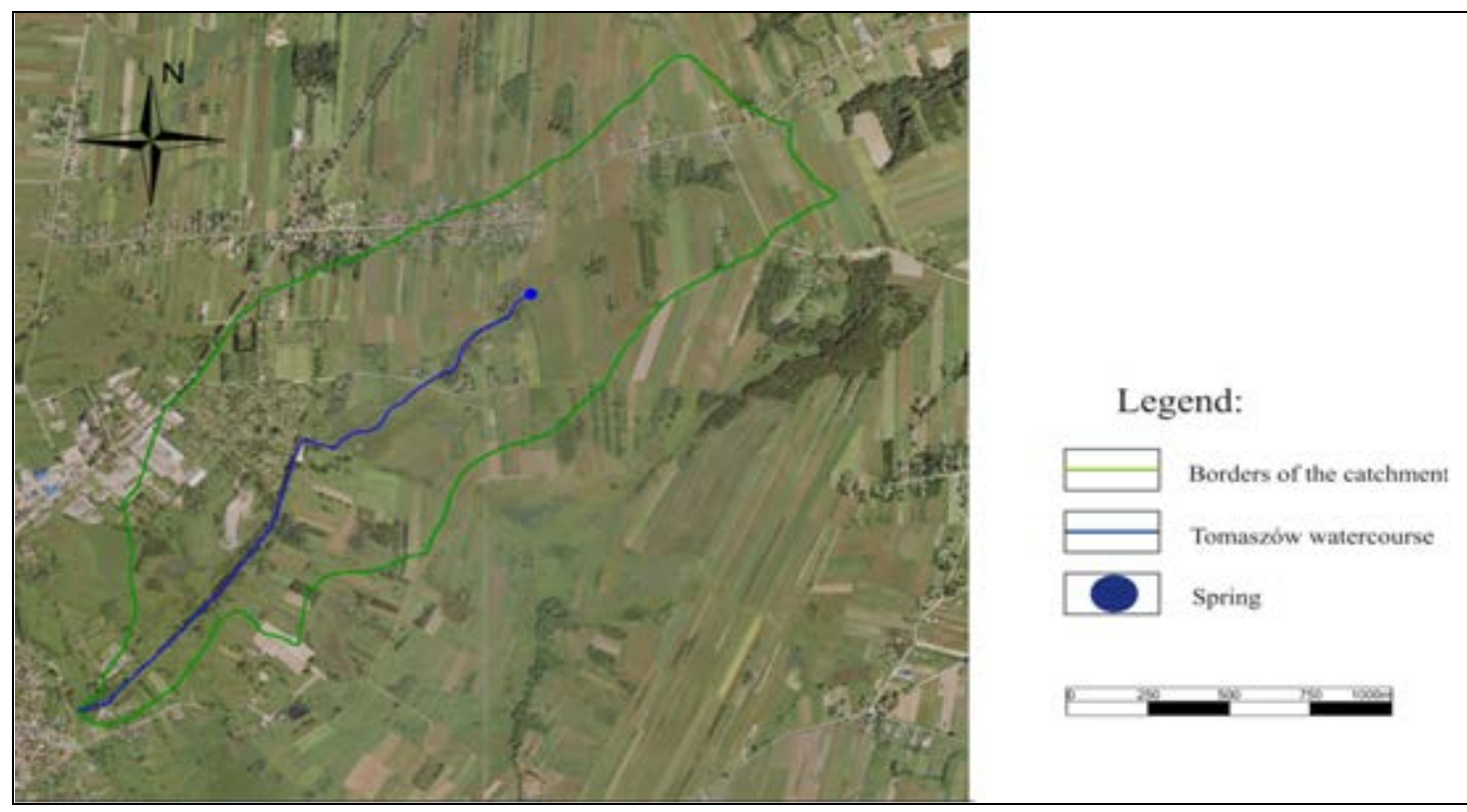

Figure 1: Location of the watercourse and its catchment on the background of orthophotomap (source: www.geoportal2.pl).

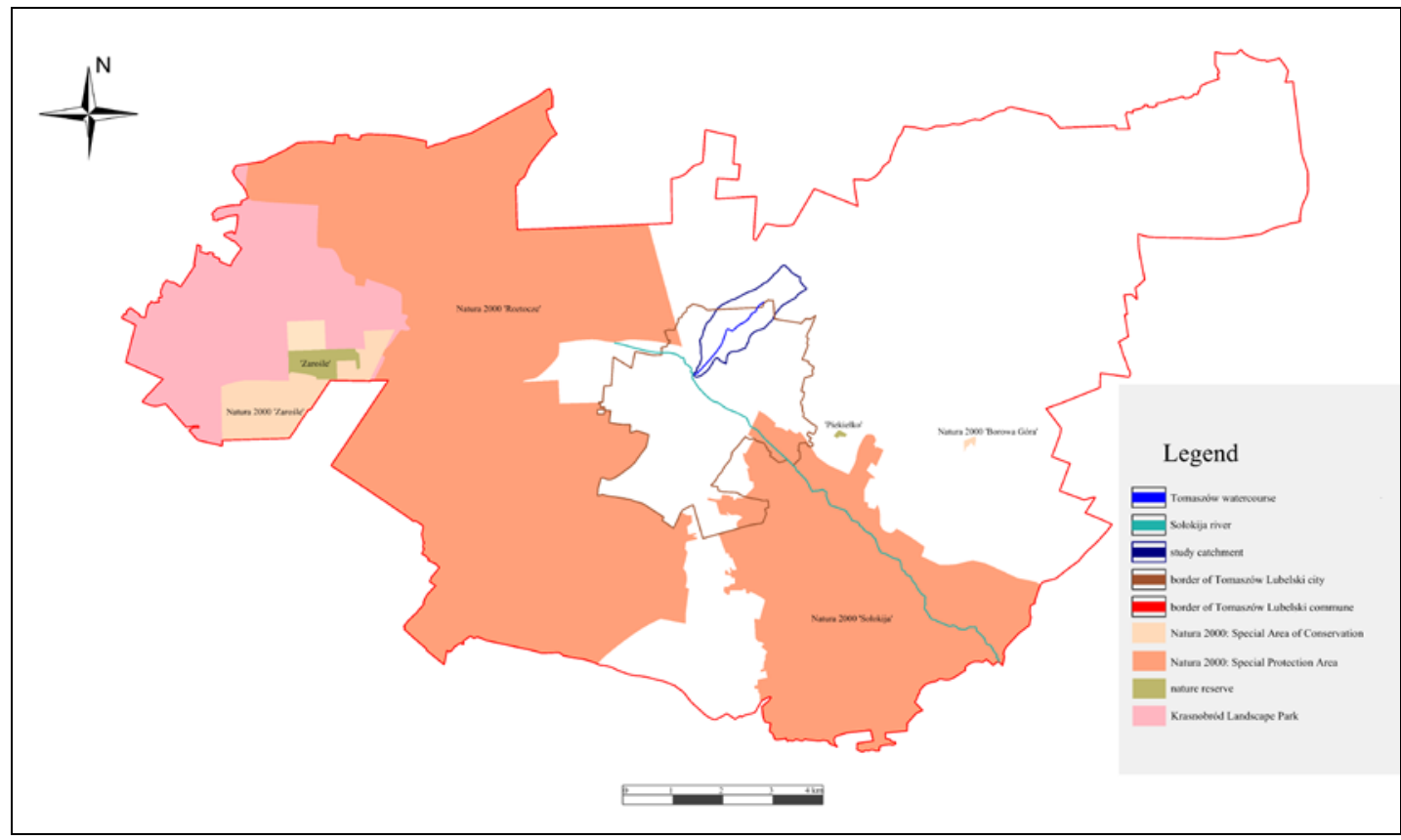

Figure 2: Distribution of protected areas on the background of research area. 


\section{Methodology}

The first part of the study focused on the assessment of environmental characteristics of the river landscape. The analysis of land use changes for the watercourse' catchment area in a period of 20 years was undertaken. For this purpose the following materials were used:

- a topographic map in a scale 1:10,000 - year 1992,

- $\quad$ an orthophotomap in a scale 1:10,000 - year 2012.

Maps were taken from Geoportal service by Geoxa Viewer programme, 2.0.0.6275 version. PowerDraft V8i programme by Bentley Company was used to perform the analysis.

\section{Qualification of the environmental state of river landscape}

Environmental conditions of the river landscapes were expressed using the ecological stability coefficient (ESC). The value of ecological stability of the area was expressed by the following formula (Jakubinsky, 2014):

$$
\mathrm{ESC}=\frac{p m \times K_{p} p}{p}
$$

where: pn - is area of mapped long term land use; $\mathrm{p}$ - an area of whole territory; Kpn - value of the coefficient of environmental land use significance.

The ESC values were calculated for the entire catchment areas in 1992, as well as in 2012. It let us describe the ecological stability of the river landscape along the watercourse and indicate tendency in land management.

\section{Qualification of ecological state of a watercourse}

The River Habitat Survey (RHS) classification was carried out by a standard method along the entire length of the river, divided into seven segments, spaced about $300 \mathrm{~m}$ from each other (Fig. 3). Choices of these segments were dictated by a different degree of their naturalness and types of anthropogenic transformations.

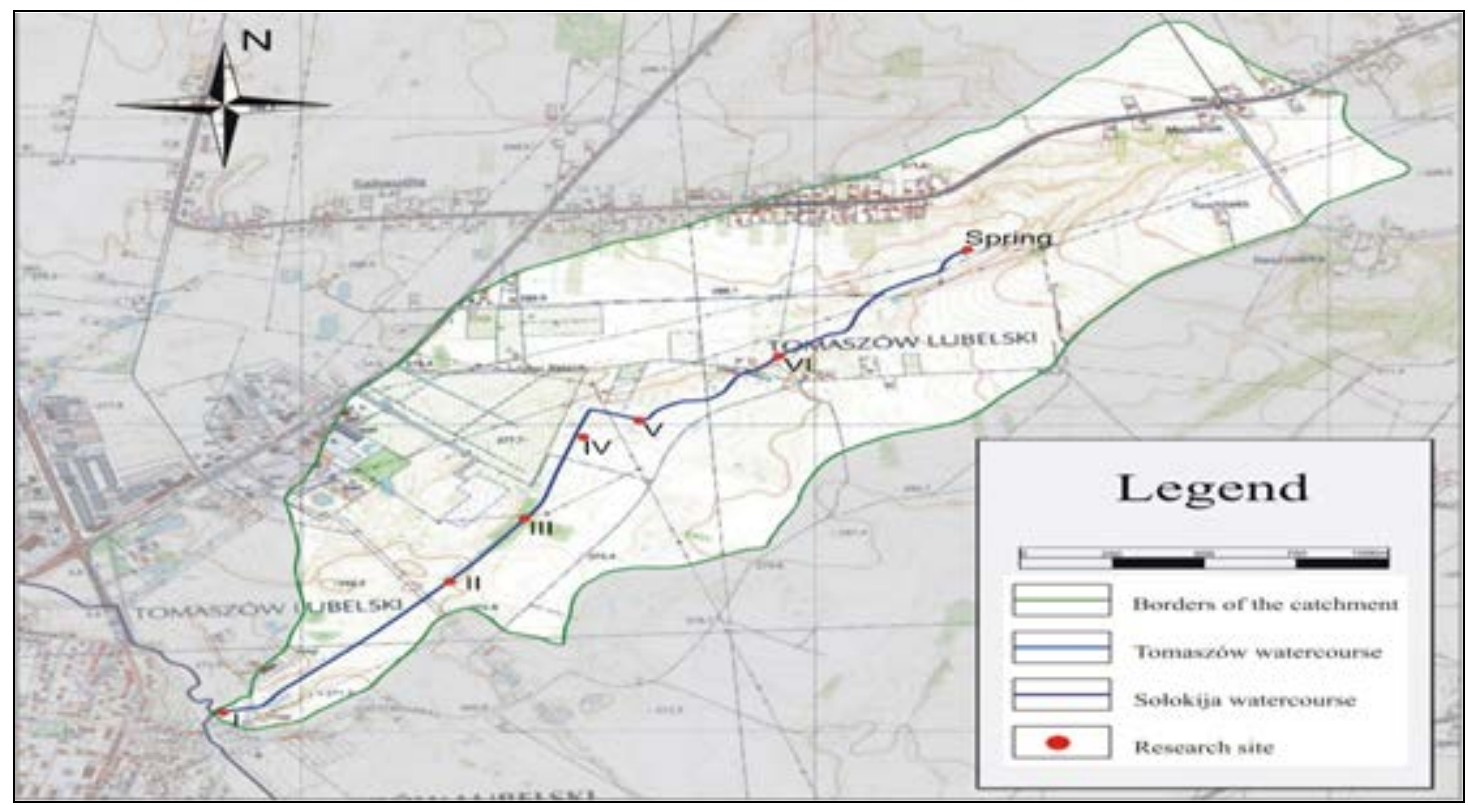

Figure 3: Catchment area and distribution of research sites along the watercourse. 
Fieldwork was conducted in May, July, and September 2012. This included a standard set of analyses covered by the RHS method, which consisted of RHS field work form as the basis. These results were then transformed into numerical values allowing for assessment of hydromorphological status of surveyed segments of the river and their classification (Szoszkiewicz et al., 2009a). For this purpose, the indicators as the result of many individual parameters were used, i.e. indicator of watercourse naturalness (Habitat Quality Assessment HQA) based on the presence and diversity of the natural elements of the stream and the river valley, as well as indicator of habitat transformation (Habitat Modification Score - HMS), defining the scope of transformation in the stream morphology (Raven et al., 2000).

Analysis of the reach started at the river spring (N 50.469408, E 23.445672) and finished in the estuary to the Sołokija River (N 50.456445, E 23.423195).

For HQA and HMS synthetic indexes limits of five classes of the hydromorphological status were specified (Lawniczak and Gebler, 2011; Raven et al., 1998; Walker et al., 2002).

For HQA the ranges of each class were proposed: I: $\geq 57$, II: 56-50, III: 49-37, IV: 3631, V: $\leq 30$, whereas for HMS index: I: 0-2, II: 3-8, III: 9-20, IV: 21-44, V: > 45.

\section{Qualification of physico-chemical parameters}

The studies of physical and chemical parameters were carried out in seven research sites: no. 1 - just $1.5 \mathrm{~m}$ before the estuary of the watercourse to the Sołokija River (watercourse flowed through wetlands overgrown with bushes and low trees); no. 2 - about $200 \mathrm{~m}$ from the garbage dump, marshy area, a line of trees along the watercourse; no. 3 - the closest point to the garbage dump; no. 4 - watercourse transformed into flooding, adjacent allotment gardens; no. 5 - watercourse flows out of wetlands, no. 6 - a fishing pond combined with the watercourse; no. 7 - a spring of the river (Fig. 3).

In each research site the following measurements were carried out:

- $\mathrm{pH}$ of water (by a microprocessor pH-meter SP3000, Slandi Company);

- electrolytic conductivity;

- oxygen content (by a microprocessor oxygen meter with a thermometer So3000, Slandi Company);

- $\quad$ nitrate and nitrogen;

- phosphates.

Water samples were analyzed using microchip SlandiSP. In order to determine water purity class ranges the Regulation of the Minister of Environment from nine November 2011 was used (Regulation of the Minister of the Environment, 2011) (Tab. 1).

Table 1: Ranges of water purity classes.

\begin{tabular}{|l|l|c|c|c|}
\hline \multirow{2}{*}{ Indicator } & \multirow{2}{*}{ Unit } & \multicolumn{3}{c|}{$\begin{array}{c}\text { Purity } \\
\text { classes }\end{array}$} \\
\cline { 3 - 5 } & & I & II & Unclassified \\
\hline Dissolved oxygen & $\mathrm{mg} \mathrm{O}_{2} / \mathrm{dm}^{3}$ & $\geq 7$ & $\geq 5$ & Limit values are not established \\
\hline Dissolved oxygen & $\mathrm{mg} \mathrm{O}_{2} / \mathrm{dm}^{3}$ & $\geq 7$ & $\geq 5$ & Limit values are not established \\
\hline Dissolved oxygen & $\mathrm{mg} \mathrm{O}_{2} / \mathrm{dm}^{3}$ & $\geq 7$ & $\geq 5$ & Limit values are not established \\
\hline Dissolved oxygen & $\mathrm{mg} \mathrm{O}_{2} / \mathrm{dm}^{3}$ & $\geq 7$ & $\geq 5$ & Limit values are not established \\
\hline Dissolved oxygen & $\mathrm{mg} \mathrm{O}_{2} / \mathrm{dm}^{3}$ & $\geq 7$ & $\geq 5$ & Limit values are not established \\
\hline Dissolved oxygen & $\mathrm{mg} \mathrm{O}_{2} / \mathrm{dm}^{3}$ & $\geq 7$ & $\geq 5$ & Limit values are not established \\
\hline
\end{tabular}




\section{RESULTS AND DISCUSSION}

Analysis of the catchment under study

The south-western and central part of the catchment area is located in the borders of Tomaszów Lubelski city, while the rest is located on municipal land, among a few villages: Sabaudia, Majdanek and Resztówka.

Height above the sea level increases gradually from the South-West to the North-East. Gorges are located in the northern and north-western part of the catchment.

The southern part of the study area was occupied by agriculture fields, meadows and highly hydrated wastelands. In the western part there were industrial buildings (building warehouses, publican warehouse, and garbage dump), garden plots, as well as urban and rural residential buildings. In the north and east parts there were agriculture fields, meadows, forests and rural buildings. The area gradually rose up until the White Mountain Hill (Fig. 4).

Analysis of catchment land use forms in 1992 and 2012 revealed the direction and rate of changes. In the 1990s the analysed study area was dominated by agriculture fields and meadows. Based on the analysis of the 2012 year, the study area had comparably decreased in land occupied by agrocoenoses. More than half the surface of meadows have overgrown, and much of the agricultural land is now forested (Tab. 2).

In areas with high water content, fish ponds have been created, consequently forming numerous backwaters and ponds in the watercourse valley (Fig. 4). In the study area there is now significant diversification of land use forms with a predominance of natural forms. Anthropogenic infrastructure is also beginning to replace cultivated fields. Due to the location of the watercourse, it is difficult to avoid such a trend.

Changes associated with an increase in the ecological stability of the watercourse catchment were confirmed by ESC indicator. Indicator values rose from 0.32 in 1992 to 0.42 in 2012, and although low, they showed a growth trend.

In general, areas dominated by agricultural land and built-up areas are referred to as unstable landscape matrix. Only areas dominated by natural elements are described as ecologically stable. Unfortunately, the current dominant land use within the catchment, as well as the ESC value led to the classification of this wastercouse as unstable.

Table 2: Land use forms in studied catchment in 1992 and 2012.

\begin{tabular}{|c|c|c|c|c|}
\hline Land use forms/year & 1992 & 2012 & 1992 & 2012 \\
\hline Farmlands & \multicolumn{3}{|c|}{ Area (ha) } & \multicolumn{2}{c|}{ Area (\%) } \\
\hline Meadows & 104.14 & 81.47 & 55 & 43 \\
\hline Forest/shrubs & 47.60 & 27.59 & 25 & 14 \\
\hline Water body/wetlands & 8.06 & 27.12 & 4 & 14 \\
\hline Urban area/build-up area & 6.01 & 22.06 & 3 & 12 \\
\hline ESC indicator & 24.23 & 32.80 & 13 & 17 \\
\hline
\end{tabular}




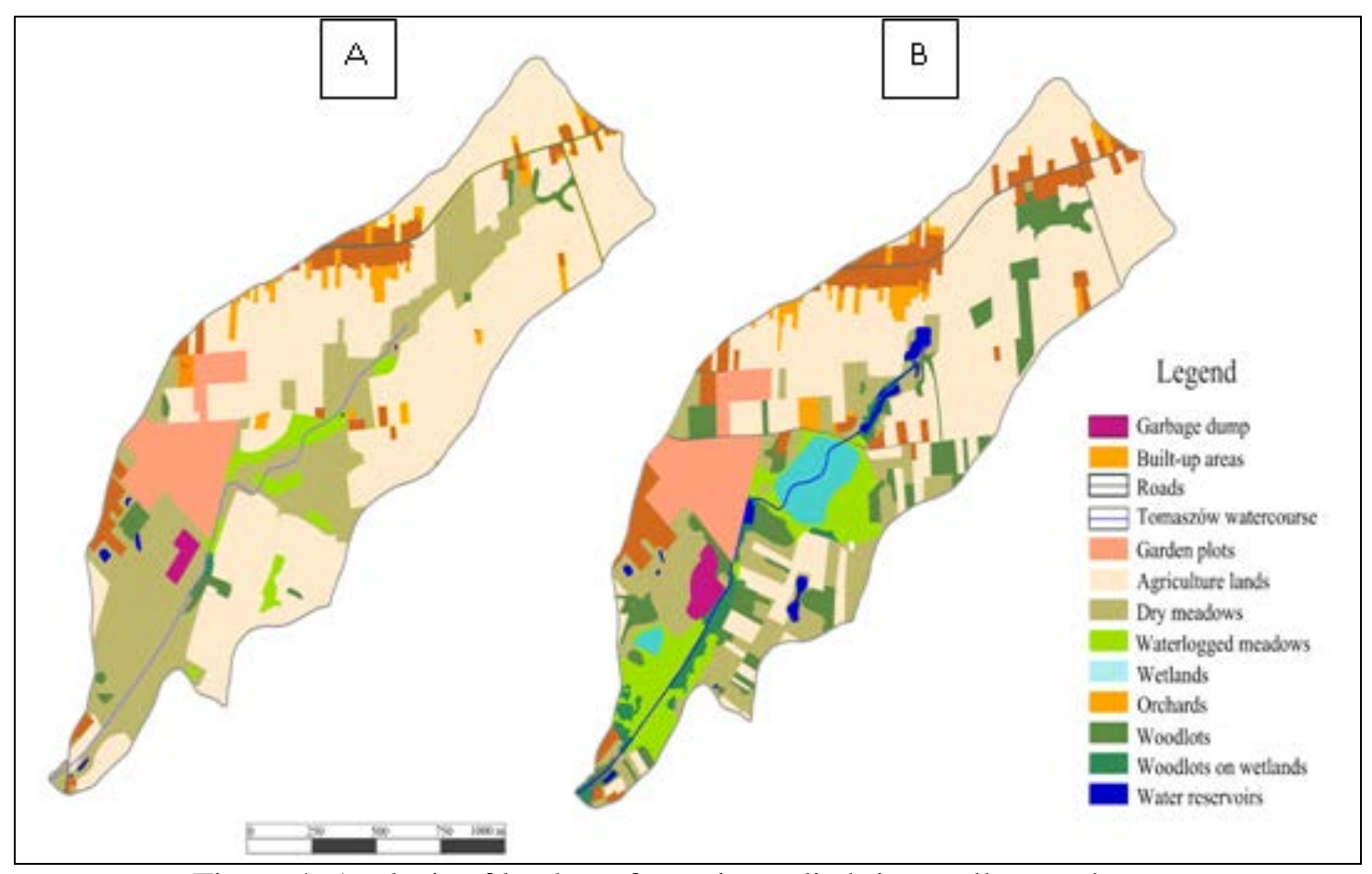

Figure 4: Analysis of land use forms in studied river valley catchment

A) 1992, B) 2012.

\section{Watercourse and river valley's naturalness assessment based on HQA index}

The data obtained from field measurements was used to assess naturalness of the watercourse and the river valley (Tab. 3).

Table 3: Results of ranking hydromorphological parameters in the calculation of the HQA natural habitat index.

\begin{tabular}{|c|c|c|c|c|c|c|}
\hline Hydromorphological parameters/studied river segments & 1 & 2 & 3 & 4 & 5 & 6 \\
\hline Type of flow & 5 & 4 & 4 & 4 & 2 & 6 \\
\hline Natural material of trough’ bottom & 4 & 3 & 3 & 3 & 3 & 4 \\
\hline Natural morphological elements of trough & 2 & 1 & 0 & 0 & 2 & 0 \\
\hline Natural morphological elements of banks & 3 & 3 & 3 & 3 & 3 & 3 \\
\hline Structure of shoreline vegetation & 13 & 13 & 14 & 13 & 8 & 11 \\
\hline Groups of aquatic plants & 3 & 0 & 1 & 6 & 4 & 6 \\
\hline Land use in $50 \mathrm{~m}$ belt from banks & 2 & 2 & 3 & 1 & 3 & 0 \\
\hline Plantings and accompanying morphological elements & 8 & 10 & 10 & 7 & 0 & 5 \\
\hline Valuable natural elements of the river environment & 0 & 0 & 1 & 5 & 1 & 4 \\
\hline Sum = HQA & 40 & 36 & 39 & 42 & 26 & 39 \\
\hline Naturalness of the watercourse and river valley & 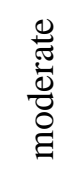 & ¿ั & 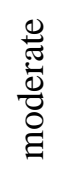 & 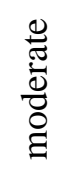 & 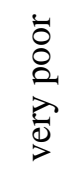 & 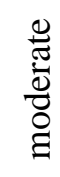 \\
\hline
\end{tabular}


Values of HQA index for the Tomaszów watercourse ranged between 26 and 42 . The highest values of this index were achieved in segments no. I and IV, which is related to the occurrence of natural material in the trough bottom, natural morphological elements of bottom and banks, plantings in the immediate surroundings and wetlands. The lowest value of the index was indicated in segment no. $\mathrm{V}$, in which the watercourse flows close to the ponds complex and to the vicinity of build-up area.

Assessment of the anthropogenic transformation degree of the watercourse and the river valley on the basis of HMS index

Values of HMS index of the Tomaszów watercourse ranged from three (segment IV) to 21 (segment I) (Tab. 4).

Table 4: Results of ranking anthropogenic modifications in the calculation of the HMS habitat modification index.

\begin{tabular}{|c|c|c|c|c|c|c|}
\hline Hydromorphological parameters/studied river segments & 1 & 2 & 3 & 4 & 5 & 6 \\
\hline Transformations observed in the control profiles & 13 & 4 & 4 & 3 & 8 & 5 \\
\hline Water structures not recorded in the control profiles & 8 & 0 & 0 & 0 & 8 & 0 \\
\hline $\begin{array}{l}\text { Transformations observed during the assessment of } \\
\text { synthetic profiles, not registered in the control }\end{array}$ & 0 & 0 & 0 & 0 & 0 & 1 \\
\hline Sum = HMS & 21 & 4 & 4 & 3 & 16 & 6 \\
\hline Degree of river' modification & 䲩 & ठั. & ס̊ & ठั & 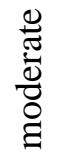 & $\begin{array}{l}\text { 겸 } \\
\text { ․ }\end{array}$ \\
\hline
\end{tabular}

Four of the analysed segments of watercourse were characterized by low anthropogenic transformations. The estuary watercourse, located near to the leachate of the disused garbage dump was the most transformed of all the segments assessed (Fig. 5).

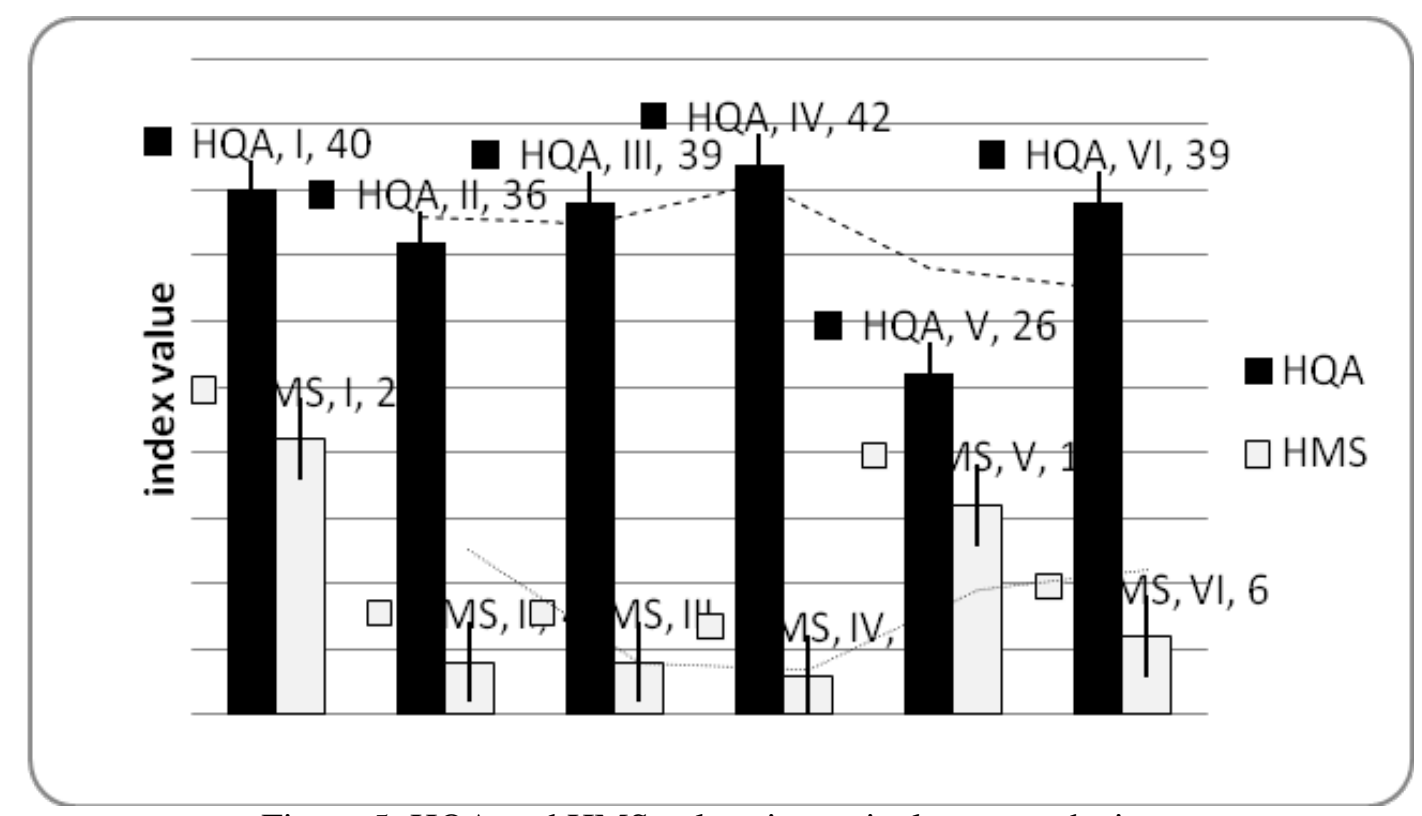

Figure 5: HQA and HMS values in particular research sites. 
Banks along the entire length of the watercourse consisted of natural materials, with small fragments of concrete structures. The dominant material of the bottom was clay and river sediments, as well as sand. Edge transformations were minimal along the entire length of the watercourse, however, garbage did occur in a few segments. Water structures were present on each of the segments, of which, culverts were the most common. For almost the entire length of the watercourse smooth flow type dominated. Typical water vegetation occurred in only four segments, whereas numerous species of liverworts and mosses occurred in the fourth segment, and rooted plants with trailing shoots in water occurred along the shores of most segments. In segments close to built-up areas, especially garbage dump and fish ponds, an invasive plant species frequently occurred.

\section{Evaluation of hydromorphological status of studied river segments}

The final classification of the hydromorphological status of the watercourse (Bielak et al., 2012) was made based on the HQA and HMS numerical indexes. Where each of the studied segments were assigned a Roman numeral representing the state of classification (Tab. 5).

The analysis showed that $62 \%$ of the investigated watercourse was characterized by moderate hydromorphological state, whereas a poor state was observed in $38 \%$ of the watercourse length. Unfortunately, no areas were characterized as having good or very good status withinin this assessment.

Table 5: Hydromorfological classification of studied river segments based on the RHS classification diagram; I - very good state, II - good, III - moderate, IV - poor, V - very poor. Numbers 1-7 refer to the river segments within this study (Bielak et al., 2012).

\begin{tabular}{|c|c|c|c|c|c|c|}
\hline & \multicolumn{5}{|c|}{$\begin{array}{c}\text { Categories } \\
\text { of HQA index values }\end{array}$} \\
\hline & & $\geq 57$ & $56-50$ & $49-37$ & $36-31$ & $\leq 30$ \\
\hline \multirow{5}{*}{ 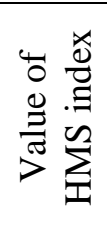 } & $0-2$ & $\mathrm{I}$ & II & II & III & III \\
\hline & $3-8$ & II & II & III- $3,4,6$ & III-2 & IV \\
\hline & $9-20$ & III & III & III & $\mathrm{IV}$ & $\underline{\mathrm{IV}-5}$ \\
\hline & $21-44$ & III & IV & IV-1 & IV & $\mathrm{V}$ \\
\hline & $45-100$ & IV & IV & $\overline{\mathrm{V}}$ & $\mathrm{V}$ & $\mathrm{V}$ \\
\hline
\end{tabular}

\section{Assessment of purity water class of studied watercourse}

Based on the physical and chemical parameters the majority of the watercourse was classified as belonging to the first class of purity, in all but two cases (Tab. 6). The first of which was observed in one of the fish ponds, where water quality could not be classified. In the vicinity of the pond, cultivated fields were also located on the slopes, above Sabaudia Village. The second discrepancy occurred within a garbage dump leaching into the watercourse, which was classified as a second class of water purity (Fig. 6). 
Table 6: Chosen physical and chemical properties of water and purity classes.

\begin{tabular}{|c|c|c|c|c|c|c|c|c|}
\hline \multicolumn{2}{|c|}{$\begin{array}{l}\text { Parameters/ } \\
\text { research site }\end{array}$} & $\begin{array}{c}\text { A } \\
\text { spring }\end{array}$ & VI & $\mathrm{V}$ & IV & III & II & I \\
\hline \multirow[b]{2}{*}{ 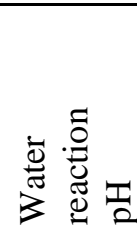 } & $\begin{array}{l}\text { Mean } \\
\text { value }\end{array}$ & $\begin{array}{c}7.87 \pm \\
2.2\end{array}$ & $\begin{array}{c}7.7 \pm \\
2.6 \\
\end{array}$ & $\begin{array}{c}7.87 \pm \\
3.3\end{array}$ & $\begin{array}{c}7.66 \pm \\
2.3\end{array}$ & $\begin{array}{c}7.73 \pm \\
3.1\end{array}$ & $\begin{array}{c}7.88 \pm \\
3.5\end{array}$ & $\begin{array}{c}7.72 \pm \\
1.9\end{array}$ \\
\hline & $\begin{array}{l}\text { Water } \\
\text { quality }\end{array}$ & I & I & I & I & I & I & I \\
\hline \multirow{2}{*}{ 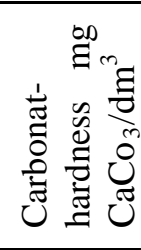 } & $\begin{array}{l}\text { Mean } \\
\text { value }\end{array}$ & $\begin{array}{c}219.6 \pm \\
12.5 \\
\end{array}$ & $\begin{array}{c}180.3 \pm \\
7.8 \\
\end{array}$ & $\begin{array}{c}156.2 \pm \\
14.9 \\
\end{array}$ & $\begin{array}{c}198.2 \pm \\
22.3 \\
\end{array}$ & $\begin{array}{c}164.9 \pm \\
31.7 \\
\end{array}$ & $\begin{array}{c}212.8 \pm \\
15.9 \\
\end{array}$ & $\begin{array}{c}211.9 \pm \\
14.9 \\
\end{array}$ \\
\hline & $\begin{array}{l}\text { Water } \\
\text { quality }\end{array}$ & I & I & I & I & I & I & I \\
\hline \multirow[b]{2}{*}{ 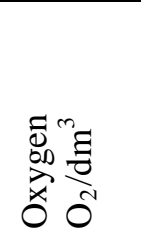 } & $\begin{array}{l}\text { Mean } \\
\text { value }\end{array}$ & $\begin{array}{c}10.2 \pm \\
2.7 \\
\end{array}$ & $\begin{array}{c}14.7 \pm \\
3.8 \\
\end{array}$ & $\begin{array}{c}10.3 \pm \\
3.2 \\
\end{array}$ & $\begin{array}{c}12.9 \pm \\
4.1 \\
\end{array}$ & $\begin{array}{c}18.3 \pm \\
4.4 \\
\end{array}$ & $\begin{array}{c}18.1 \pm \\
4.9 \\
\end{array}$ & $\begin{array}{c}7.5 \pm \\
1.4 \\
\end{array}$ \\
\hline & $\begin{array}{l}\text { Water } \\
\text { quality }\end{array}$ & I & I & I & I & I & I & I \\
\hline \multirow{2}{*}{ 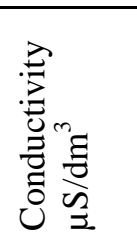 } & $\begin{array}{l}\text { Mean } \\
\text { value }\end{array}$ & $\begin{array}{c}383.7 \pm \\
21.4 \\
\end{array}$ & $\begin{array}{c}510.3 \pm \\
32.2 \\
\end{array}$ & $\begin{array}{c}472.7 \pm \\
33 \\
\end{array}$ & $\begin{array}{c}534.3 \pm \\
45\end{array}$ & $\begin{array}{c}615 \pm \\
47.9 \\
\end{array}$ & $\begin{array}{c}736.3 \pm \\
63.1 \\
\end{array}$ & $\begin{array}{c}696.3 \pm \\
52.1 \\
\end{array}$ \\
\hline & $\begin{array}{l}\text { Water } \\
\text { quality }\end{array}$ & I & I & I & I & I & I & I \\
\hline \multirow{2}{*}{ 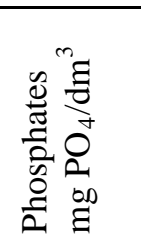 } & $\begin{array}{l}\text { Mean } \\
\text { value }\end{array}$ & $\begin{array}{c}0.047 \pm \\
0.03 \\
\end{array}$ & $\begin{array}{c}0.32 \pm \\
0.02 \\
\end{array}$ & $\begin{array}{c}0.127 \pm \\
0.005 \\
\end{array}$ & $\begin{array}{c}0.057 \pm \\
0.001 \\
\end{array}$ & $\begin{array}{c}0.044 \pm \\
0.003 \\
\end{array}$ & $\begin{array}{c}0.273 \pm \\
0.05 \\
\end{array}$ & $\begin{array}{c}0.167 \pm \\
0.096 \\
\end{array}$ \\
\hline & $\begin{array}{l}\text { Water } \\
\text { quality }\end{array}$ & I & $\begin{array}{l}\text { uncla- } \\
\text { ssified }\end{array}$ & I & I & I & II & I \\
\hline \multirow{2}{*}{ 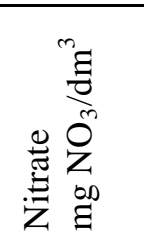 } & $\begin{array}{l}\text { Mean } \\
\text { value }\end{array}$ & $\begin{array}{c}1.155 \pm \\
0.7 \\
\end{array}$ & $\begin{array}{c}1.027 \pm \\
0.56 \\
\end{array}$ & $\begin{array}{c}0.075 \pm \\
0.078 \\
\end{array}$ & $\begin{array}{c}0.07 \pm \\
0.004 \\
\end{array}$ & $\begin{array}{c}0.118 \pm \\
0.021 \\
\end{array}$ & $\begin{array}{l}0.4 \pm \\
0.015 \\
\end{array}$ & $\begin{array}{c}0.191 \pm \\
0.056\end{array}$ \\
\hline & $\begin{array}{l}\text { Water } \\
\text { quality }\end{array}$ & I & I & I & I & I & I & I \\
\hline
\end{tabular}

According to the current Water Framework Directive, member states of the European Union are required, inter alia, to protect water and aquatic ecosystems maintaining a good condition, as well as to improve water quality of degraded waters by human activities. This can maintain a balance of aquatic ecosystems, both for the direct benefit of humans, as well as to preserve natural water heritage. The Tomaszów watercourse did not fulfil the requirements of the Water Framework Directive, because its state was defined as poor and moderate. In a similar study, only one of seven studied segments within the Bochotniczanka River was in a good state (Maślanko and Sender, 2014). 
The garbage dump is one of the main anthropogenic elements degrading the Tomaszów watercourse. Former garbage dump sites are a nationwide problem (Allgaier and Stegmann, 2006; Goran and Dušan, 2012; Laner et al., 2012). Despite the passing time, both on the closure of the garbage dump, as well as the introduction of the Water Framework Directive, this dump is in a state of deep neglect. Weaknesses have been observed in regards to the position of the dump, as it is located at a distance of approximatively five meters from the current watercourse, and its slope descends almost directly to the water.

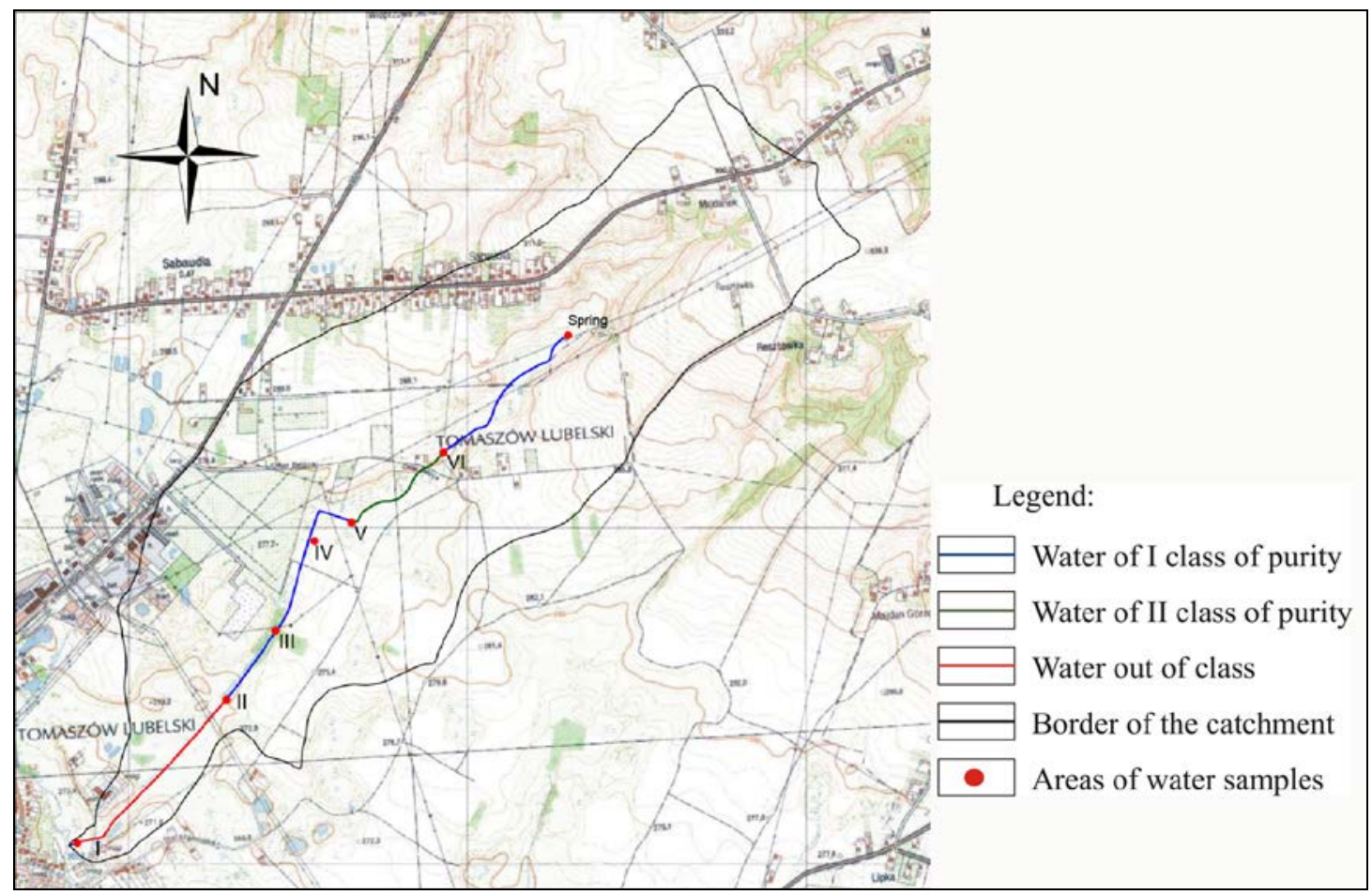

Figure 6: Purity classes in particular segments of studied watercourse.

This dump was also not fully subjected to any reclamation between 1992 and 2012. Its southern slope has not been covered by soil, and rubbishes scattered around the dump, visible from a far distance. In spring 2014 a pollutant leachate was clearly visible flowing from the bare slope to the stream. Upstream of the garbage dump, nearby water has increased turbidity, and in the bottom and middle layers water appeared as a rusty brown sludge.

Fish ponds were also found to be a degrading influence on the water purity and environment quality of the Tomaszów watercourse (Rzętała, 2008; Carr and Goulder, 1990; Boaventura et al., 1997; Wiesmann et al., 1988). The watercourse in the upper part flows through the land used for fish farming, and the impact of this economy can be seen in the form of increased concentration of nutrients, which resulted in the unclassified status of these segmenting terms of physical and chemical parameters. 
These arguments proved that in the protection of surface water significant neglects occurred. The absence of dump reclamation in the study area is contrary to the main requirements of the Minister of the Environment, including the location, construction, exploitation and closure, which should correspond to the different types of garbage dumps from 24 March 2003 (Journal of Laws from 2003, no. 61, item 549), as well as to the Water Framework Directive, according to which member states should take care to protect water quality in all its aspects. The overriding purpose for conducting garbage dump reclamation process should be minimizing its potential negative impact on the environment.

Surroundings of Tomaszów Lubelski constituted areas with a high natural potential. A large number of protected areas exist, among which only four were founded in the 21st century; one in 2011 and three in 2007. Many various hiking and educational trails occur within the area, and protection is subjected to many species of plants and animals living in suitable habitats. Continuity of protected areas and areas of nature attractiveness of the whole Roztocze region, are suggested based on the existence of an important ecological corridor in this region. Despite this, human activities carried out in this area indicated serious negligence, leading to environmental degradation. As a consequence, this may lead to a deterioration of the quality of life and human health risks.

The results of the assessment by the RHS method allowed an increased attention to the potential of the area, but it has been weakened. According to the HQA index, the best result was a moderate value of the watercourse naturalness. In some segments the state was defined as poor or very poor. The area defined as very poor, however, includes the section where water flows from ponds followed by wetlands, which are valuable due to the presence of water purifying plants characteristic for such habitats. On this segment water flows calmly, spilling into several themes, which contributes to water purification, and after passing through this area the water returns to a first class of purity (Barling and Moore, 1994; Dhote and Dixit, 2009). Unfavourable results of RHS index again highlighted neglects towards the protection of this area, and a lack of efforts to achieve standards established by the Water Framework Directive.

The evaluation of purity water class of the Tomaszów watercourse indicated it is in much better condition than described by RHS method. The condition of each segment range from the first class of waters to unclassified water class. Of the measured water quality variables, a high concentration of phosphate was a limiting factor. Based on data from the Report of District Environment Programme, the Sołokija River, to which waters of the Tomaszów watercourse flows, in 2005 was assessed as V water class purity. Increased phosphate content in this river was also one of the factors determining the water purity class. Despite the ecological potential of the area, water from the Tomaszów watercourse and the Sołokiji River do not fulfill conditions set out in the Water Framework Directive, which indicates neglect of the entire catchment area (Report on the implementation of the tasks set out in the District Environment Programme).

\section{CONCLUSIONS}

Within the years spanning the comparison of conditions (1992-2012) land use change and anthropogenic development have occurred within the study area. A gradual intensity of natural succession has also been observed. Agriculture fields have overgrown and transformed into meadows, whereas former meadows and pastures are overgrown by bushes and trees, while simultaneously intensive building process have increased. Despite the position of the watercourse in the potentially favourable areas, outside a compact urban built-up, values of HMA and HQA indicators were defined as moderate or average. 
The current biggest threats for the Tomaszów watercourse are point emitters of pollutants spaced along the entire length of the watercourse. Sanitary conditions should be promptly improved, and in particular adjacent garbage dump requires reclamation. This dump also affects the aesthetics of riparian areas. Additional threats include fishing and pollution from agriculture. Among ways to prevent pollution of river waters, it is important to exclude these threats from the hydrological line course with ponds, reducing fisheries management and implementation of trees and shrubs on steep slopes to reduce surface water runoff from farmland.

\section{REFERENCES}

1. Allan J. D., Erickson D. I. and Fay J., 1997 - The influence of catchment land use on stream integrity across multiple spatial scales, Freshwater Biology, 37, 149-161.

2. Allgaier G. and Stegmann R., 2006 - Preliminary assessment of old landfills, in Proceedings of Seminario-Workshop Tecnologie per la riduzione degli impatti e la bonifica delle discariche, Montegrotto Terme, Padova, Italia June, 7-9.

3. Bajkiewicz-Grabowska E. and Mikulski Z., 2007 - General hydrology, PWN Science Publishing Company, Warsaw, 4th edition, changed zmienione and revised, reprint. (in Polish)

4. Barling R. O. and Moore I. O., 1994 - Role of buffer strips in management of waterway pollution: a review, Environmental Management, 18, 4, 543-558.

5. Bielak S., Baran K., Kulig N. and Ścierska E., 2012 - Application of the River Habitat Survey in the assessment and classification of the hydromorphological status of rivers and streams of southern Polish, in accordance with the requirements of the Water Framework Directive Czasopismo Techniczne, Środowisko, 23, 3-16. (in Polish)

6. Boaventura R., Pedro A. M., Coimbra J. and Lencastre E., 1997 - Trout farm effluents: characterization and impact on the streams, Environmental Pollution, 95, 3, 379-387.

7. Byczkowski A., 1999 - Hydrology, I, SGGW Publishing Company, Warsaw.

8. Carr O. J. and Goulder R., 1990 - Fish-farm effluents in rivers - II. Effects on inorganic nutrients, algae and the macrophyte Ranunculus penicillatus, Water Research, 24, 5, 639-647.

9. Chmielewski T. J., 2004a - River valleys as the accumulation zone of contamination and corridors of movement of pollutants in the landscape, in Cieszewska A. (ed.), Patches and corridors as part of the landscape structure - the possibilities and limitations of the concept, Problemy Ekologii Krajobrazu, XIV, Wyd. SGGW Warszawa, 176-177. (in Polish)

10. Chmielewski T. J., 2004b - New quality of landscape: ecology-culture-technology, Zesz. Nauk. Komit. "Człowiek i Środowisko" przy Prezydium PAN, no. 36, Warszawa-Lublin, 1-158. (in Polish)

11. Chmielewski T. J., 2005 - The diversity of landscape of Lublin Region: Problems of assessment and protection, Przyroda i Człowiek, z. 12, Stow Opolskie Centrum Edukacji Ekology Opole, 17-34. (in Polish)

12. Chmielewski T. J., Sowińska-Świerkosz B., Kułak A. and Chmielewski S., 2014 - Landscapes of the Roztocze region: Natural and Cultural Heritage, Scientific monograph, Publishing house of the University of Life Sciences in Lublin, 194.

13. Curtean-Bănăduc A., Schneider-Binder E. and Bănăduc D., 2014 - The importance of the riverine ligneous vegetation for the Danube Basin lotic ecosystems, in Cianfaglione K. (ed.), L’importanza degli Alberi e del Bosco. Cultura, scienza e coscienza del territorio, Edit. Temi, Trento, Italia, ISBN: 978-88-973772-63-9, I-II, 187-210.

14. Dhote S. and Dixit S., 2009 - Water quality improvement through macrophytes - a review, Environmental Monitoring Assessment, 152, 149-153. 
15. Directive 2000/60/EC of the European Parliament and of the Council of 23 October 2000 establishing a framework for Community action in the field of water Policy, Official Journal L 327, 22/12/2000, 0001-0073.

16. Goran V. and Dušan M., 2012 - Waste management, direction of future scientific research, Reciklaža i Održivi Razvoj, 5, 1, 30-38. (in Polish)

17. Jakubínský J., 2014 - The human impact on the current hydromorfological states of small watercourses in the Czech Republic, Ecohydrology and Hydrobiology, 14, 4, 313-322, doi:10.1016/j.ecohyd.2014.08.001.

18. Journal of Laws from 2003, 61, item 549.

19. Laner D., Crest M., Scharff H., Morris J. and Barlaz M., 2012 - A review of approaches for the long-term management of municipal waste landfills, Waste Management, 32, 3, 498-512.

20. Ławniczak A. E. and Gebler D., 2011 - Supporting hydromorphological elements, in assessment of the ecological status of water catchment Wel. Guidelines for integrated assessment of the ecological status of rivers and lakes for the purpose of management plans for the river basin, Soszka H., (ed.), Wyd. Instytutu Rybactwa Śródlądowego, Olsztyn, s. 127-139. (in Polish)

21. Maślanko W. and Sender J., 2014 - Hydromorfological valorisation of the Bochotniczanka River valley as a potential valuable ecological corridor in the Lublin region, TEKA, Commission of Protection and Formation of Natural Environment, Polish Academy of Sciences, Branch in Lublin, XI, 90-98.

22. Newson M. D., Clark M. J., Sear D. A. and Brookes A., 1998 - The geomorphological basis for classifying rivers, Aquatic Conservation: Marine and Freshwater Ecosystems, 8, 415-430.

23. Osowska J. and Kalisz J., 2011 - Use of the method of the River Habitat Survey to exploit hydromorphological of the river Kłodnica Górnictwo i geologia, 6, 3, 141-156. (in Polish)

24. Raven P. J., Holmes N. T. H., Dawson F. H. and Everard M., 1998 - Quality assessment using River Habitat Survey data, Aquatic Conservation: Marine and Freshwater Ecosystems, 8, 477499, John Wiley and Sons, Ltd., Great Britain, 477-499.

25. Raven P. J., Holmes N. T. H., Naura M. and Dawson F. H., 2000 - Using river habitat survey for environmental assessment and catchment planning in UK, Hydrobiologia, 422, 359-367.

26. Regulation, 2011 - Regulation of the Minister of Environment of 9th November 2011, On the classification of ecological status, ecological potential and chemical status of surface water bodies, Acts Laws no. 258, item 1549.

27. River Habitat Survey, 1997 - Field survey guidance manual, Environmental Agency, Bristol.

28. River Habitat Survey in Britain and Ireland, 2003 - Field survey guidance manual, Environment Agency, Warrington, 1-74.

29. Rzętała M., 2008 - The assessment of touristic and recreational significance of water reservoirs (Upper Silesia region), in shaping the geographical environment and nature protection in industrialized and urbanized areas. WBiOŚ UŚ, WNoZ UŚ, Katowice - Sosnowiec, s, Publishing house of Silesia University, Katowice, 94-105. (in Polish)

30. Sender J. and Maslanko W., 2014 - Diversity of aquatic ecosystems in urban areas - public expectations, Transylvanian Review of Systematical and Ecological Research, The Wetlands Diversity, 16.1, 125-134.

31. Szoszkiewicz K., Zgoła T., Jusik Sz., Hryc-Jusik B., Dawson F. H. and Raven P., 2009a Hydromorphological assessment of flowing waters. Guide to the fieldwork according to the method River Habitat Survey in Polish conditions Warrington, Poznań, 133. (in Polish)

32. Szoszkiewicz K., Zgoła T., Giełczewski M. and Stelmaszczyk M., 2009b - Application of the River Habitat Survey to exploit hydromorphological status and impact assessment of planned re-naturalization activities, Nauka, Przyroda, Technologie, 3, 3, 1-9. (in Polish)

33. Walker J., Diamond M. and Naura M., 2002 - The development of physical habitat objectives, Aquatic Conservation: Marine and Freshwater Ecosystems, 12, 381-390.

34. Wiesmann D., Scheid H. and Pfeffer E., 1988 - Water pollution with phosphorus of dietary origin by intensively fed rainbow trout (Salmo gairdneri Rich.), Aquaculture, 69, 3, 263-270. 